\title{
Democratization and elitism in the EU: two opposing trends (Guest-Editor's introduction to the topical collection on "The Future of Europe")
}

\author{
Markus Pausch
}

Received: 28 November 2014 / Accepted: 28 November 2014 /Published online: 10 December 2014

(C) The Author(s) 2014. This article is published with open access at Springerlink.com

\begin{abstract}
Europe has been facing a multi-dimensional crisis since 2008 with a strong impact on the quality of democracy in the EU and its member states. The continuous loss of citizens' support threatens the very existence of the EU more than any other dimension of the crisis. For decades, the legitimacy of European politics was based on a permissive consensus and Pareto-efficient outputs, but since the late 1990s and especially as a direct consequence of economic problems, cuts in social systems and an emerging gap between the rich and the poor, the output-legitimacy is no longer sufficient. Today, the future of decision making and the democratization of the EU have become burning issues for the Union's stability. In the light of rising scepticism and distrust in political elites all over Europe, further democratization is urgently needed. European policy makers are well aware of this. Since the 1990s, there have been discussions about a democratic deficit. And even since the late 1970s, a trend towards the democratization of the European Communities and the EU has been perceptible with a steady strengthening of the European Parliament. To date, however, all these efforts could neither fully eradicate the democratic shortcomings of EU decision making nor avoid mistrust and disinterest among European citizens. This paper argues that the European Union has developed an elitist or Schumpeterian democracy and that democratization continues to this day, albeit slowly. It is, however, bypassed by the trend towards extending the gap between elites and citizens which foils the democratization process and threatens European integration as a whole.
\end{abstract}

This article is part of the Topical Collection on The Future of Europe, guest-edited by Markus Pausch

M. Pausch $(\bowtie)$

Centre for Futures Studies, Salzburg University of Applied Sciences, Urstein Sued 1, 5412 Puch, Salzburg, Austria

e-mail: markus.pausch@fh-salzburg.ac.at
Keywords European democracy $\cdot$ EU trends · Democratization $\cdot$ Elitism $\cdot$ Inequality

Introduction: the European union as an elitist democracy

The topical collection of the European Journal of Futures Research on "The Future of Europe" addresses some issues that are crucial to the further development of the Union such as the concept of cosmopolitanism (Erik Oddvar Eriksen), the future of individualization (Nikolai Genov), the study of right-extremism in Europe (Steven van Hauwaert), energy policy and the relations to Russia (Johannes Pollak, Samuel Schubert and Elina Brutschin), the European dimension of Russian identity (Anastasia Likhacheva, Igor Makarov and Ekaterina Makarova), the neglected futures of the poor (Helmut Peter Gaisbauer and Clemens Sedmak), the European dimension of education (Alfonso Diestro Fernández), foresight in the European Commission (Jean-Claude Burgelman, Jarka Chloupková and Werner Wobbe), the future of European governance (Shana McLean), the future of counter-terrorism (José María Blanco and Jéssica Cohen) and European resource efficiency (Meghan O'Brien et al.). My introductory paper argues that the European Union has developed an elitist or Schumpeterian democracy and that democratization continues to this day, albeit slowly. It is, however, bypassed by the trend towards extending the gap between elites and citizens which foils the democratization process and threatens European integration as a whole.

The European integration process started in the 1950s as an elitist project based on a permissive consensus and on a strong output. As Giandomenico Majone argues, the EC was Paretoefficient for a very long time [1]. With a small number of member states, the decision-making procedures were reduced 
to intergovernmental negotiations and initiatives by the high authority, the later Commission. The European Parliament only had a consultative role and rights to control but no legislative function. Its members were appointed by their nation states and not directly elected. The democratic legitimacy of the European Communities was thus based on the permissive consensus and a well perceived output [2]. The first steps of democratization were taken only in the late 1970s. In 1979, the introduction of direct elections to the European Parliament made its members more accountable. Although these first direct elections did not strengthen the powers of the EP, they can be considered as the first stage in a long, slow and still ongoing process of democratization [3]. In the early 1990s, the Treaty of the European Union gave more powers to the EP, and the Lisbon Treaty from 2007 made it the main player in the co-decision procedure of EU legislation. Although democratization cannot be seen as a linear development and was sometimes overtaken by other trends and backlashes, the general quality of institutional democracy at EU level has improved over the last decades. "In sum, in the course of the past 50 years, the European Community has evolved from a regional organization that was not concerned with human rights or the regime of new member states and did not have more than a symbolic parliamentary representation, into a liberal democratic multilevel polity" [4]. Compared to national democracies, however, EU democracy remains on a relatively basic level [5]. It can be qualified as an elitist or Schumpeterian model of democracy which is characterized by the strong dominance of politicians and bureaucrats and a minor role for the citizens [6]. ${ }^{1}$

This applies to the elitist making of the EU and the so called permissive consensus that characterized citizens' behaviour towards the integration process. Although the founding fathers are not suspicious of having had a similar picture of citizens' competences as Schumpeter, they did not invest a great deal of effort in generating broad public debates about European integration. The building of a "High Authority" and its directorates are very strong proof of the elitist notion of the first European institutions. Citizens elected politicians at national level who then took decisions at supranational level. This provoked very long chains of legitimacy and a lack of public control. Voters could not intervene any further. They could not bring up any issues nor could they decide on them-a characteristic case of Schumpeterian democracy [7]. The elitist notion of EU politics remains strong till this day. Despite new ways of multi-level governance and deliberative democracy [8], the majority of citizens do not

\footnotetext{
${ }^{1}$ Such Schumpeterian democracy is often referred to as a competitive model, where citizens only elect their representatives but do not intervene during legislation periods. Joseph Schumpeter's concept of an elitist democracy was created in the first half of the 20th century and should describe nation states. Although it cannot fully be applied for the EU, there are some interesting correlations and analogies.
}

have ways to "intervene" which also has something to do with the complexity of decision-making procedures. Even if the concept of governance with a broader integration of stakeholders, interest groups and NGOs was introduced as new way of democratic decision-making in the late 1990s [9], the circle of decision-makers remains an elitist one. As Paul Magnette argues, the attempts to strengthen governance procedures produced an elitist citizenship of sorts, meaning that only those who are very active and well-organized at European level have the possibility to influence decisionmaking indirectly by lobbying as well as in green or white paper procedures. "In these conditions, citizenship in the European Union is likely to remain an elitist practice, limited to those citizens and groups who benefit from their intellectual and financial resources to try and influence EU politics and policies" [10].

Thus, in its present form, the European Union does indeed demonstrate numerous characteristics of a Schumpeterian democracy. It remains elitist in its decision-making procedures. The agenda is set by the executive more than by the legislative power since the quasi monopoly of initiative is in the hands of the European Commission. Important policy fields such as Treaty reforms, fiscal and taxation policy or Foreign Policy still underlie unanimous decisions in the EU Council. The Union has a well-established bureaucracy and citizens can hardly intervene during legislation periods.

Nevertheless, even with the minimalist definition of democracy in the sense of Schumpeter, there were always shortcomings in the EU, which were, however, only addressed quite recently: 1 . Political competition; 2 . The role of the parliament. In Schumpeter's view, the main criterion for a democracy was the competition for political leadership. $\mathrm{He}$ compared such competition with a market place where candidates try to sell their goods and where the most convincing politician wins. A political system without such competition would not fulfil the minimum criteria and thus not be qualified as democracy. If taken seriously, the EU only very indirectly corresponded to such a form of democracy for most of the time of its existence. Until 2014, there was no competition for political leadership at EU level. The Commission President was announced by the European Council and accepted by the Parliament, but did not go through a competitive election campaign. Only the national representatives in the Council had limited legitimation to represent their countries in the EU. Furthermore, many policies were and still are decided by complex and intransparent methods of consensus-finding in lobbies and the back rooms of EU institutions. Simon Hix has shown that EU integration has in general even led to a decline in political competition in various policy fields, because competences which were supranationalised by European law had lost their public arena of competition. "Democracy is (...) about the ability of voters to choose between rival groups of elites, with rival candidates for political leadership and rival 
programmes for public policy. Not only does this competition allow voters to reward or punish leaders for their action, but it also promotes policy debate, deliberation, innovation and change" [11].

\section{Four trends of democratization in the EU}

Hix' statement is still true today for a number of policy fields but despite all the shortcomings which exist there is a trend towards democratization in the EU.

\section{Democratization trend 1: more political competition}

The ability to choose at EU level was strengthened by the election campaign of 2014. For the first time in European integration, the European party families agreed on leading candidates who fought for the position of Commission president. This innovation in the making of a Commission made the European Union more democratic in the sense of a Schumpeterian democracy. It is quite probable that future elections to the EP will be even more competitive than the one in 2014.

A further proof of stronger competition is the number and ideological variety of candidates in the last elections. Not only have the three big political families, the Popular Party, Social Democrats and Liberals, announced their leaders, but the Greens and the Left have done likewise. The number of party groups in the EP is higher than ever before, the majority of the big three has declined. This will strengthen public competition about policy fields.

\section{Democratization trend 2: stronger role of the European parliament}

According to the minimalist democracy of Schumpeter, parliaments should have the power to keep or to refuse the leadership of the prime minister, but concerning concrete issues, they should decide more by acceptance than by initiative [12]. The European Parliament does in fact not have the right for initiative, but today it has a strong position in keeping or refusing the Commission. Its inter-institutional role has changed considerably since the late 1970s, when direct elections were held for the first time. Since then, it has grown continuously in importance and today it has the power to veto or stop legislation. Although it still does not have the right for initiative, its role was continuously strengthened and this trend most certainly continues. The new Commission can be considered a strong ally for the EP that shares at least some of its main claims in the inter-institutional game. Compared to national parliaments or strong parliamentary systems, the EU will probably not reach more than a minimalist stage of democracy in the next 5 to 10 years. However, the institution and its representatives will continue claiming for more rights. As a survey among German speaking MEPs from all political parties shows, there is a relatively broad consensus that Parliament should be further strengthened. Most of the MEPs interviewed pleaded for a right to speak in national parliaments and promote the idea of a federal European constitution [13]. The election of the Commission President by the European Parliament is a quasi-unanimous claim of all MEPs except for those who plead for a renationalization or dissolution of the EU. A majority promotes the idea of European electoral lists and campaigns of European parties instead of national party campaigns. As one MEP put it: "EU elections are currently overshadowed by national issues. They are interpreted as second order elections by many parties. European electoral lists could strengthen political discourse at the European level and help to build a European public sphere" [13]. As the survey shows, the representatives of the European Popular Party, Liberals, Social Democrats, Greens and Leftists are for a democratization of the EU and a strengthening of the EP. Only the MEPs of the extreme right wish a renationalization and a re-democratization of the national states. One representative claims "the European Parliament to be the Assembly of the delegates from national Parliaments" [13], because only national parliaments were democratically legitimated. This shows that democratization is a big issue among all MEPs. While the pro-Europeans want to democratize the EU, anti-Europeans prefer the "re-democratization" of member states. Since the latter are clearly in a minority position in the EP, it is very probable that the supranational democratization trend will be further promoted by the EP.

Democratization trend 3: more rights for citizens to set the agenda

As argued above, the decision-making procedures in the EU have been democratized by more competition and a strengthening of the EP, even if the initiation of legislation is still an exclusive right of the European Commission. In order to also offer some more opportunities for citizens' intervention, for the first time in supranational history, a direct democratic element was included in the Lisbon Treaty: The European Citizens' Initiative. "A European citizens' initiative is an invitation to the European Commission to propose legislation on matters where the EU has competence to legislate. A citizens' initiative has to be backed by at least one million EU citizens, coming from at least 7 out of the 28 member states. A minimum number of signatories is required in each of those 7 member states" [14]. This new instrument has already been used by many different initiatives, two of which successfully took the hurdle of 1 million signatures. It is to expect that citizens' possibilities to set the agenda will further be strengthened in the next years by more information on 
existing ways of intervention on the one hand and the topdown initiation of European Citizens' initiatives on the other.

\section{Democratization trend 4: good governance}

The fourth trend of democratization is the already mentioned approach of "good governance", introduced by the European Commission under President Romano Prodi in 2001. In the White Paper on Governance, five principles were formulated: Openness, participation, accountability, effectiveness and coherence. These principles should be respected in European legislation processes. In general, it can be defined as the attempt to include as many stakeholders, NGOs and interest groups as possible in non-hierarchic debates and deliberation. The success and the shortcomings of these practices have been analysed [15] and evaluated differently. However, the awareness of the Commission is undoubtedly a positive development. As stated in the original White Paper: "Civil society plays an important role in giving a voice to the concerns of the citizens and delivering services that meet people's needs" [16]. Nevertheless, the formal commitment to a broader inclusion and an elitist awareness could not yet successfully open the decision-making procedures to a broad public. Only a few groups of citizens have the resources to participate, and thus a kind of elitist citizenship has emerged. The suggested ways of governance in the EU have not yet overcome the distance between elites and citizens. A trend towards strengthening the principles of good governance will, however, go on under the new Commission President, Jean-Claude Juncker, who has already stressed the importance of transparency and openness on several occasions [17].

\section{Four trends of an emerging gap between elites and citizens}

The four trends of democratization are bypassed by four other trends which undermine democratic procedures in the European Union. They have to do with an emerging gap between elites and citizens and an ever stronger scepticism towards the EU and its representatives. The acceptance of the Union and its politics by the citizens of Europe has never been overwhelming. Since the 1990s, scepticism among Europeans and the number of Eurosceptic political parties has increased. Today, Pascal Perrineau and other political scientists identify a democratic crisis which is characterized by a reluctance concerning political elites and institutions [18] Although different instruments for the measurement of the quality of democracy such as the Democracy Barometer or the Democracy Index do not show a general decline of democratic quality in Europe [19], Perrineau is right to depict a crisis of trust. This crisis has to do with the supranationalization of politics [20] and other trends that open the gap between elites and citizens. Today, Euroscepticism is a well-known and wide spread phenomenon which is closely linked to the question of democratic decision-making in the EU. Taken together, one can identify four important trends of a rising gap between elites and citizens.

Rising gap trend 1: increasing socio-economic inequalities

Different studies show very clearly that the socio-economic inequalities in the member states of the European Union have been rising during the last decades. Data from the OECD show that income inequality is at its highest level for the past half century. For most of the European countries, there is a clear trend towards more inequality. "In general, the $10 \%$ highest income recipients have seen their income grow much more rapidly than the rest of the population over the last 25 years" [21]. Also, the rate of relative poverty has been rising in many countries. The Gini coefficient which measures income inequality on a scale from 0 (identical incomes for all) and 1 (all income in the hands of only one person) rose significantly in 17 of 22 OECD countries and in some European countries in particular: namely Finland, Germany, Luxembourg or Sweden [22]. In an OECD report from 2008 entitled "Growing Unequal?", inequality has already been addressed. The report showed that "inequality in the distribution of market incomes - gross wages, income from self-employment, capital income, and returns from savings taken together - increased in almost all OECD countries between the mid-1980s and mid-2000s" [23]. Many prominent scholars such as Colin Crouch [24], Joseph Stiglitz [25] or Thomas Piketty [26] have recently argued that an increase in inequalities also hampers democracy. It leads to disinterest, mistrust and political abstention.

Rising gap trend 2: declining trust in institutions of representative democracy and EU

In general the trust in institutions of representative democracy is declining at the regional, national and supranational level. Trust in European institutions has especially declined in the last years.

As Fig. 1 shows, trust among European citizens in the European Commission and the European Parliament decreased in the last years to less than $40 \%$. In a space of 5 years, trust in these institutions lost more than 10 percentage points. Even if a trend extrapolation were to be avoided in the years to come, one can assume that a trend reversal is also improbable. That means that by 2019 (next EP elections) or 2020 (end of the period of the EU Strategy) it can be expected that trust in the EP and the Commission will remain on a very low level or even have further declined, maybe to below $30 \%$, which would mean that more than two thirds of Europeans would 


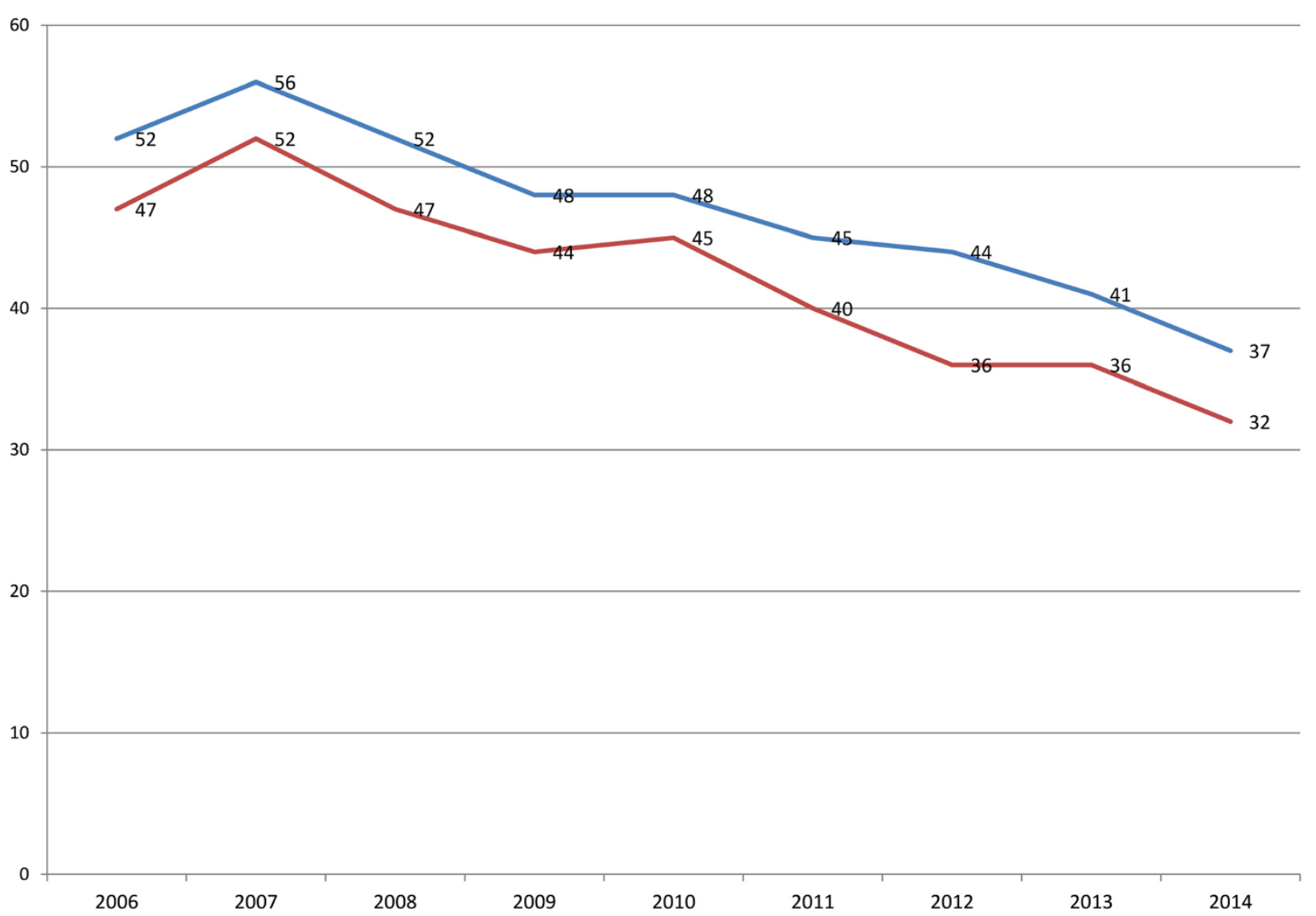

Fig. 1 Trust in EU institutions. Source: Eurobarometer Data 2006-2014 (own diagram based on data of Eurobarometer)

not trust the main supranational institutions. If we assume a very likely further strengthening of the European level with regard to legislative power, there will be a tremendous gap between law-making elites and the European citizens as legal subjects.

Rising gap trend 3: declining political participation in elections

As a consequence of the mistrust towards institutions, the political participation in elections also declines. This holds true for many national elections in EU Member States such as France, Germany, Austria, the UK, Italy and most of the EU 13 [27] but also for elections to the European Parliament as Fig. 2 shows.

There is a contradictory situation concerning EP-elections. While the powers of the EP have been importantly strengthened since 1979, the participation in elections declined over the same period. This means that voters renounced their right to vote although their legal possibilities to influence EU policies have risen. If we consider not only the ever lower turnout in EU elections but include also the many residents who have no political right to vote (people living in the EU without EU citizenship), then the absolute number of nonvoters in European elections rises to 250 million adult persons who either abstained from voting or were unable to vote because they were non-EU citizens. This is an alarming number. Presuming a further trend of non-voters and non-EU citizens, it is possible that two thirds of all adults living in the European Union will not participate in the elections to the European Parliament in 2019. Such a low turnout would undoubtedly have a deep impact on the legitimacy of the EU and threaten its very existence.

\section{Rising gap trend 4: anti-European extremism}

The emergence of anti-European extremism in the party landscape in Europe goes hand in hand with this crisis of democracy. Anti-Europeanism or hard Euroscepticism [27] is characterized by opposition to the European Union as a matter of principle. Soft Euroscepticism is opposed to a further European integration. Both forms have become stronger in the last years. Today, Eurosceptic parties from the extreme right and from the extreme left have more seats in the European Parliament than ever before. Right wing extremism is on the way to entering a fifth stage of its development since the Second World War which is the stage of supranationalization. Although it still remains difficult for anti-Europeans to unite at supranational level, they have taken the first steps in this direction and would appear to be becoming stronger. The openly anti-EU Parliamentary Groups, Europe of Freedom and Direct Democracy, won 48 seats in 


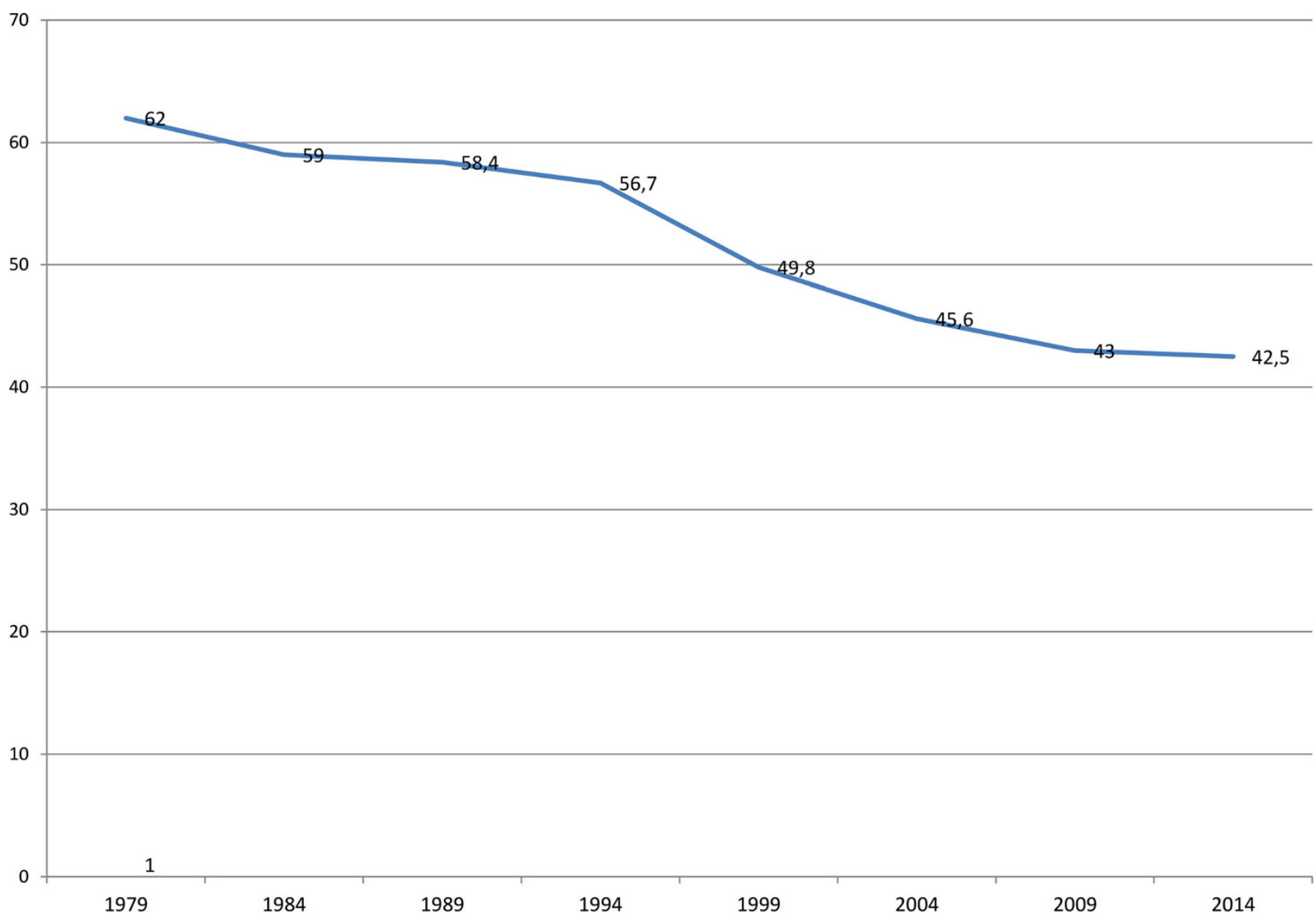

Fig. 2 Participation in EU elections. Source: Own diagram based on data of European Parliament Website; http://www.europarl.europa.eu/ elections2014-results/en/turnout.html

the last elections, the soft-Eurosceptic European Conservative and Reformists Group has 71 members. Trends 1 to 3 of the rising gap between elites and citizens directly support trend 4 , anti-European extremism. It is thus presumable that unless inequality and mistrust are stopped, the share of anti-European parties especially from the nationalist right-extremists will increase in the next European Parliament that is elected in 2019.

\section{Conclusions: European democracy needs a trend reversal}

Two opposing trends can be identified in the European Union: An institutional democratization that makes the Union more accountable, transparent and representative on the one hand; a widening gap between elites and citizens that makes it more selective and exclusive on the other hand. Although the EU elites are well aware of these trends, they did not manage to find sustainable answers. The future of Europe, however, depends a lot upon the acceptance and perception of the European citizens. Elitist democracies, as they were defined by Joseph Schumpeter, can fail in only a few years. The biggest challenge for the next 5 to 10 years will, therefore, be the reversal of the trends which widen the gap between elites and citizens. This is a difficult but not unsolvable task. Some of the problems that need to be addressed are mentioned in the Strategy Europe 2020. Bringing elites closer to the citizens and vice versa can be supported by different steps. Most important is the fight against inequalities and unemployment. The following measures should be taken into consideration:

a) Convergence criteria for employment

The burning social problems need to be tackled in European wide measures. Since the problems are European, the solutions cannot be national. This means that the EU needs the power to act on social policy. Thus, only a shift of competence from the national to the supranational level can stop social dumping and help to introduce European wide social standards. EU strategies for growth and inclusion need to be backed by binding decisions in Council and Parliament. The convergence criteria should include the unemployment rates of the member 
states. This suggestion is not new. Today's Commission President, Jean-Claude Juncker, expressed this already in 1997 in an interview with the German magazine Der Spiegel: "We need criteria of convergence for employment in order to exert pressure on all the governments to fight unemployment" [28]. Juncker claimed that in the European Council, the heads of states and governments should justify their employment rates. As criteria of convergence for unemployment in the member states, he suggested taking the mean of the three countries with the lowest unemployment figures [28].

b) Youth guarantee

The "youth guarantee" that ensures that every young European under 25 gets a good quality offer, thus either a job, apprenticeship, traineeship or education, needs to be filled with content and concrete actions [29]. The Commission plans to strengthen co-operation and the exchange of experiences or best practice. In order to be really efficient, the "youth guarantee" needs to be an integral part of a European wide social policy and could also be included in the criteria for convergence as suggested by Juncker in the late 1990s.

c) Further politicization of the EU

The politicization of the EU that recently was strengthened by the competition for votes during the EP elections needs to go on, as was also suggested by Ingolf Pernice and a group of EU experts in 2012: "Competences in the field of economic and fiscal policies, taxation etc. touch among the most relevant individual concerns of the citizen. At the latest at the stage of European integration, the recognition of the political role of the Commission and the need for more direct impact of the European elections on the policies led by the Commission are necessary." [30]. Pernice suggested that party families should present their common candidate for the office of the President of the Commission. This became reality in 2014. He further proposed that this person should simultaneously hold the office of the President of the Council. In this case, "the EU would have a personal face, and this doublehatted President would, with both offices, be accountable to the European Parliament. A similar procedure could be applied also to the other members of the Commission, with each party family presenting their top candidate for this office in each Member State" [31].

d) More visibility of EU politicians in national public spheres

The strengthening of the European Parliament as legislator needs to be combined with a visible role for EU politicians in national public spheres. So far, one of the most striking problems with respect to the gap between elites and citizens is the distance to the EU representatives. This could be addressed by the introduction of a right to speak for EU politicians in plenary sessions in the parliaments of the
Member States. Members of the Commission could be interrogated in question hours not only in the EP, but also in national Parliaments. Following Pernice's suggestion of Commission candidates in each Member State, these candidates could then be accountable to the parliaments. Such measures would give visibility to EU politicians, foster public discourse and bring about a kind of European public sphere [32]. Moreover, MEPs should in general have more time and resources for the exchange with their voters, be it in discussions, events or online.

e) Strengthening of European citizenship education

As a long term measure, European citizenship education should be strengthened. Today, most Europeans do not have sufficient knowledge and information of how the EU works, what history it has and - most importantlywhat ways of inclusion and political participation it offers. As long as Europeans do not have this knowledge, they will tend to feel far away from the EU. A strengthening of the European dimension in education also includes language courses and exchange programs. Furthermore, young Europeans should have visited the European institutions during their secondary education, have the possibility to talk to MEPs and people from the Commission and get the tools to act politically at the supranational level.

f) Political Rights and EU citizenship for third-country nationals

European Citizenship depends upon the citizenship of a Member State. This should be rethought in the light of ever more restrictive national citizenship legislation and an ever higher share of third-country nationals living in the Union. Today, more than 30 million people who live in the EU have no right to vote in EP-elections. This represents a threat to the democratic legitimacy of Europe. It should be seriously discussed, how long-term residents of third countries can get political rights at the supranational level.

g) Further constitutionalization and clear responsibilities

Ten years after the rejection of the Constitutional Treaty by the French and the Dutch and in the light of an ongoing economic and political crisis, the European elites should reconsider the necessity of constitutionalization. Part of such a constitutionalization should be the repatriation of all Treaties that were introduced in order to fight the crisis, especially the Treaty on Stability, Coordination and Governance in the Economic and Monetary Union. Although they did not break EU law, they were something outside of EU treaties. Bruno de Witte states that "... with regard to the content of the Fiscal Compact, the adoption of EU legislation would have been preferable - from the perspective of democratic legitimacy and legal stability." [33]. Now, the new treaties need to be rethought and made compatible with EU legislation, especially with the Community Method, 
in order to get the EP involved [34]. Further constitutionalization of the Union should in any case be based on a Convention similar to the one of the early 2000s, but with one important difference: The members of this Convention should be directly elected by the Europeans - and the result should be approved (or rejected) in a European wide referendum. A democratization of the EU can only be successful if the trend of a rising gap between elites and citizens can be stopped and if the Union's basic rules are decided by the European people.

Open Access This article is distributed under the terms of the Creative Commons Attribution License which permits any use, distribution, and reproduction in any medium, provided the original author(s) and the source are credited.

\section{References}

1. Majone G (1993) The European Union between social policy and social regulation. Eur J Common Mark Stud 31(2): $153 \mathrm{f}$

2. Hooghe L, Marks G (2008) A postfunctionalist theory of European integration: from permissive consensus to constraining dissensus. $\mathrm{Br}$ J Polit Sci 39(I):1-23

3. Rittberger B (2012), Institutionalizing representative democracy in the European Union: the case of the European parliament 50(1): $18 \mathrm{f}$

4. Schimmelfennig F (2009), The normative origins of democracy in the European union: towards a transformationalist theory of democratization, working paper Nr. 39, National Centre of Competence in Research (NCCR), 4

5. Hix S, Follesdal A (2005) Why there is a democratic deficit in the EU: a response to Majone and Moravcsik. J Common Mark Stud 2006 44(3):533-562

6. Pausch M (2011) The European union: from Schumpeterian democracy to a European public sphere? Altern Turk J Int Relat 10(1):5

7. Schumpeter JA (1943) Capitalism, socialism and democracy. Routledge, New York, p 464

8. Eriksen EO, Fossum JE (2000) Democracy in the European Union: integration through deliberation? Routledge, New York

9. Hooghe L, Marks G (2001) Multi-level governance and European integration. Rownan Publishers, Oxford, p 5

10. Magnette P (2003) european governance and civic participation: beyond elitist citizenship? Polit Stud 51:13

11. Hix S (2003) The end of democracy in Europe? how the European union (as currently designed) restricts political competition; working pape, 2, http://personal.lse.ac.uk/HIX/Working_Papers/Hix-End_of_ Democracy in Europe.pdf, 2014-11-11

12. Schumpeter JA (1943) Capitalism, socialism and democracy. Routledge, New York, p $272 \mathrm{f}$

13. Pausch M (2014) Survey among German and Austrian members of the European parliament. Transcription, Salzburg

14. Website of the European Parliament; http://ec.europa.eu/citizensinitiative/public/basic-facts; 2014-11-11

15. Schmidt VA (2013) Democracy and legitimacy in the European union revisited: input, output and 'throughput'. Polit Stud 61:2-22
16. European Commission (2001) European governance - a white paper, Brussels; http://europa.eu/legislation_summaries/ institutional_affairs/decisionmaking_process/110109_en.htm, 2014-11-11

17. European Commission Website (2014), Weekly College Meeting Discusses Greater Transparency; http://ec.europa.eu/news/2014/11/ 20141119 en.htm, 2014-11-19

18. Perrineau $\overline{\mathrm{P}}$ (2007) La crise de la representation politique, Châpitre 1, in P. Perrineau and L. Rouban, La politique en France et en Europe, Presses de Sciences Po Paris, 15-34

19. Bühlmann M, Merkel W, Weßels B (2008) The quality of democracy. Democracy Barometer for established democracies, Working paper 10a in collaboration with Lisa Müller, NCCR Democracy 21, Zürich

20. Scharpf F (2003) Problem solving effectiveness and democratic accountability in the EU, MPIFG-Working paper 03, number 1 ; http://www.mpifg.de/pu/workpap/wp03-1/wp03-1.html 2014-10-31

21. Fredriksen KB (2012) Income inequality in the European Union, economic departments working papers No. 952, ECO/WKP (2012)29, 8; http://www.oecd.org/officialdocuments/ publicdisplaydocumentpdf $/$ ? cote $=\mathrm{ECO} / \mathrm{WKP} \% 282012 \%$ 2929\&docLanguage $=$ En, 2014-11-14

22. OECD (2011) An overview of growing income inequalities in OECD countries: main findings, 22; http://www.oecd.org/els/soc/49499779. pdf, 2014-11-03

23. OECD (2011) An overview of growing income inequalities in OECD countries: main findings, 23; http://www.oecd.org/els/soc/49499779. pdf, 2014-11-03

24. Crouch C (2008) Post-democracy, themes for the 21st century. John Whiley \& Sons, New York

25. Stiglitz J (2012) Price of inequality, how today's divided society endangers our future. W.W. Norton \& Company, New York

26. Piketty T (2014) Capital in the twenty first century. Harvard University Press, Harvard

27. Taggart $P$ (2003) A touchstone of dissent: euroscepticism in contemporary Western European party systems. Eur J Polit Res 33(3):363388

28. Der Spiegel (1997), Minister für Beschäftigung; http://www.spiegel. de/spiegel/print/d-8799000.html; 2014-11-20; eigene Übersetzung ins Englische

29. European Commission Website: Youth Guarantee; http://ec.europa. $\mathrm{eu} / \mathrm{social} / \mathrm{main} . j \mathrm{sp}$ ?catId=1079 2014-11-24

30. Pernice I (2012) Introduction. In: Pernice I, Maduro MP, Louis J-V, Emmanouilidis JA, et al. (eds) Challenges of multi-tier governance in the European Union: Effectiveness, efficiency and legitimacy, Directorate General for Internal Policies, Compendium Notes, $\mathrm{p} 8$. Policy Department C - Citizens' Rights and Constitutional Affairs, European Parliament, Brussels

31. Pernice I (2012) Introduction. In: Pernice I, Maduro MP, Louis J-V, Emmanouilidis JA, et al. (eds) Challenges of multi-tier governance in the European Union: Effectiveness, efficiency and legitimacy, Directorate General for Internal Policies, Compendium Notes, p 9. Policy Department C Citizens' Rights and Constitutional Affairs, European Parliament, Brussels

32. Bruell C, Mokre M, Pausch M (eds) (2009) Democracy needs dispute. The debate on the European constitution. Frankfurt am Main, Campus. Policy Department C - Citizens' Rights and Constitutional Affairs, European Parliament, Brussels

33. de Witte B (2012) European stability mechanism and treaty on stability, coordination and governance: role of the EU institutions and consistency with EU legal order. In: Pernice I, Maduro MP, Louis J-V, Emmanouilidis JA, et al. (eds) Challenges of multi-tier governance in the European Union: Effectiveness, efficiency and legitimacy, Directorate General for Internal 
Policies, Compendium Notes, p 84. Policy Department C Citizens' Rights and Constitutional Affairs, European Parliament, Brussels

34. Dehousse R (2012) Is the 'community method' still relevant? In: Pernice I, Maduro MP, Louis J-V, Emmanouilidis JA, et al. (eds)
Challenges of multi-tier governance in the European Union: Effectiveness, efficiency and legitimacy. Directorate General for Internal Policies, Compendium Notes, pp 85-94. Policy Department C - Citizens' Rights and Constitutional Affairs, European Parliament, Brussels 